\title{
Pengaruh Komitmen Organisasi Terhadap Kinerja Auditor Dengan Independensi, Integritas dan Pemahaman Good Governance Sebagai Variabel Pemoderasi (Studi Empiris pada KAP di Jawa Tengah dan DIY)
}

\author{
Nurita Elfani Prasetyaningrum ${ }^{1)}$ Rukmini $^{2)}$ \\ ${ }^{1}$ Program Studi Akuntansi Fakultas Ekonomi Universitas Surakarta \\ ${ }^{2}$ Institut Teknologi Bisnis AAS Indonesia \\ *Email korespondensi: elfaniprasetya@gmail.com
}

\begin{abstract}
This study aims to (1) analyze the effect of organizational commitment on auditor performance (2) analyze independence as a moderating effect on organizational commitment on auditor performance (3) analyze integrity as a moderating effect on organizational commitment on auditor performance (4) analyze understanding of good governance as moderating the effect of organizational commitment on auditor performance. This study uses a sample of 48 auditors working on KAP in Central Java and Yogyakarta. Sampling using a purposive sampling technique. Data analysis techniques using regression analysis with absolute difference test. The findings show (1) organizational commitment has a significant effect on auditor performance (2) independence is a moderating variable that can strengthen the effect of organizational commitment on auditor performance (3) integrity is a moderating variable that can strengthen the effect of organizational commitment on auditor performance (4) understanding of good governance is a moderating variable that can strengthen the effect of organizational commitment on auditor performance.
\end{abstract}

Keywords: organizational commitment, independence, integrity, understanding of good governance, auditor performance

Saran sitasi: Prasetyaningrum, N. E., \& Rukmini. (2020). Pengaruh Komitmen Organisasi Terhadap Kinerja Auditor Dengan Independensi, Integritas dan Pemahaman Good Governance Sebagai Variabel Pemoderasi (Studi Empiris pada KAP di Jawa Tengah dan DIY). Jurnal Akuntansi dan Pajak, 21 (1), 112120. doi: http://dx.doi.org/10.29040/jap.v21i1.1084

DOI: http://dx.doi.org/10.29040/jap.v21i1.1084

\section{PENDAHULUAN}

Profesi akuntan publik adalah profesi yang sangat penting, namun saat ini integritas para akuntan publik sudah mulai diragukan oleh pihak yang berkepentingan atas laporan akuntan publik akibat dari maraknya skandal keuangan yang terjadi akhirakhir ini. Dengan semakin banyaknya skandal keuangan yang terjadi di luar maupun di dalam negeri sangat mempengaruhi kepercayaan pengguna laporan keuangan auditan pada profesi akuntan publik (Sabirin \& Nurhayati, 2019).

Kasus Enron di Amerika yang melibatkan kantor akuntan publik Arthur Andersen ditemukan memanipulasi laporan keuangan. Perusahaan memiliki kerugian, tetapi dalam laporan keuangan, terdapat keuntungan sebesar 600 juta Dolar AS. Berdasarkan hasil Pemeriksaan, ternyata ada beberapa pejabat, seperti manajer dan staf akuntansi Enron, adalah mantan auditor di Kantor Akuntan Publik Andersen. Andersen dinyatakan bersalah karena menghalangi proses pengadilan (Hutabarat, 2012). Di Indonesia terdapat beberapa kasus, seperti temuan investigasi auditor dari Pasar Modal Badan Pengawas (Bapepam) terhadap PT Great River International, Tbk, yang mengindikasikan inflasi akun penjualan, piutang, dan aset hingga ratusan miliar rupiah yang menyebabkan arus kas perusahaan berakhir dan gagal membayar utang. Berdasarkan hasil investigasi, Bapepam menyatakan bahwa akuntan publik yang mengecek laporan keuangan PT Great River Internasional, Tbk bersalah. Selanjutnya, kasus yang sama menimpa PT Kimia Farma dan PT Bank Lippo. PT Kimia Farma melaporkan mendapat untung Rp 132 miliar. Padahal perusahaan 


\section{Jurnal Akuntansi dan Pajak, 21 (01), 2020, 113}

seharusnya hanya mendapat untung sebesar Rp 99 miliar. Sementara itu, PT Bank Lippo melaporkan laba ke publik sebesar Rp 98 miliar. Namun, beberapa bulan ke depan di laporan keuangan yang disampaikan ke Bursa Efek Jakarta menyebutkan bahwa perusahaan merugi hingga Rp 1,3 triliun (Halim et al., 2014).

Berdasarkan kasus yang disebutkan di atas, tentu saja menimbulkan keraguan tentang kinerja yang dihasilkan oleh para auditor. Sejalan dengan masalah tersebut, penting dilakukan penelitian yang mengeksplorasi variabel yang mempengaruhi kinerja auditor.

Kantor Akuntan Publik (KAP) adalah organisasi bergerak di bidang jasa antara lain audit kepatuhan, audit operasional, dan audit laporan keuangan. Dalam menjalankan profesinya, akuntan publik diatur oleh Kode Etik Akuntan Indonesia. (Trisnaningsih, 2007). Sejalan dengan berkembangnya profesi auditor dan persaingan di kalangan auditor menuntut auditor untuk selalu meningkatkan kinerjanya dengan tujuan agar dapat menciptakan auditor yang mampu menghasilkan produk audit yang berkualitas tinggi (Hanna \& Firnanti, 2013).

Auditor merupakan seseorang yang memberikan opini wajar atau tidaknya laporan keuangan diperusahaan yang sesuai dengan prinsip akuntansi umum yang berlaku di Indonesia (Mulyadi, 2002: 23). Kinerja auditor merupakan hasil kerja yang dicapai oleh auditor dalam melaksanakan tugasnya sesuai dengan tanggung jawab yang diberikan padanya, dan menjadi salah satu tolak ukur yang digunakan untuk menentukan apakah suatu pekerjaan yang dilakukan akan baik atau sebaliknya. Kinerja auditor menjadi perhatian utama, baik bagi klien ataupun publik, dalam menilai hasil audit yang dilakukan (Fanani dkk., 2008).

Komitmen organisasi adalah suatu prinsip yang dimiliki oleh seorang auditor untuk cenderung memilih organisasi tersebut dengan tujuan berupaya mempertahankan dirinya didalam organisasi tersebut (Wijana \& Ramantha, 2015). Komitmen organisasi adalah suatu keadaan dimana seseorang karyawan emihak organisasi tertentu serta tujuan dan keinginannya untuk mempertahankan keanggotaan dalam organisasi tersebut (Sapariayah, 2011). Komitmen organisasi dibangun atas dasar kepercayaan pekerja atas nilai-nilai organisasi, kerelaan pekerja membantu mewujudkan tujuan organisasi dan loyalitas untuk tetap menjadi anggota organisasi. Oleh karena itu, komitmen organisasi akan menimbulkan rasa ikut memiliki (sense of belonging) bagi pekerja terhadap organisasi. Karyawan yang komit terhadap organisasi akan menunjukkan sikap dan perilaku yang positif terhadap lembaganya, karyawan akan memiliki jiwa untuk tetap membela organisasinya, berusaha meningkatkan prestasi, dan memiliki keyakinanyang pasti untuk membantu mewujudkan tujuan organisasi (Trsinaningsih, 2007). Komitmen organisasi pada dasarnya komitmen organisasi merupakan suatu proses dalam diri individu untuk mengidentifikasikan dirinya dengan nilai-nilai, aturan-aturan dan tujuantujuan organisasi yang bukan hanya sebagai kesetiaan yang pasif terhadap organisasi, sehingga komitmen menyiratkan hubungan pegawai dan organisai secara aktif (Widhi \& Erma, 2015). Komitmen organisasi mencerminkan sejauh mana individu lebih mementingkan kepentingan organisasinya dari pada kepentingan pribadinya, sehingga individu tersebut menjadi lebih loyal terhadap organisasinya (Robbins \& Timothy, 2007). Komitmen organisasi akan muncul bila individu sadar akan hak dan kewajibannya didalam menjalankan tugasnya di organisasi tersebut tanpa memikirkan kepentingannya (Suryana, 2013).

Penelitian mengenai pengaruh komitmen organisasi terhadap kinerja auditor telah banyak dilakukan oleh peneliti sebelumnya dengan hasil temuan yang berbeda-beda. Hasil penelitian sebelumnya yang dilakukan oleh Elyawati dkk., (2010); Lawalata dkk. (2010); Sapariyah (2011), Julianingtyas (2012); Novatiani \& Mustofa (2014); Mindarti (2015); Sanjiwani dkk (2016); Fembriani \& Budiartha (2016) menyatakan bahwa komitmen organisasi berpengaruh positif dan signifikan terhadap kinerja auditor. Sedangkan penelitian yang dilakukan oleh Somers (1998); Siahaan (2010); Hanna \& Firnanti (2013); Widhi \& Setyawati (2015); Putra \& Ariyanto (2016) menyatakan hasil yang berlawanan yaitu komitmen organisasi tidak berpengaruh signifikan terhadap kinerja auditor.

Berdasarkan penelitian sebelumnya, masih terdapat ketidakkonsistenan dari hasil penelitian terdahulu. Dengan adanya hasil temuan yang berlawanan ini, peneliti tertarik untuk meneliti kembali pengaruh komitmen organisasi terhadap kinerja auditor pada KAP di wilayah Jawa Tengah dan DIY. Peneliti juga mengembangkan model dengan memasukkan tiga variabel pemoderasi yang 


\section{Jurnal Akuntansi dan Pajak, 21 (01), 2020, 114}

mungkin dapat mempengaruhi kinerja auditor, yaitu variabel independensi, integritas, dan pemahaman good governance.

Independensi auditor merupakan aspek penting bagi profesionalisme akuntan khususnya dalam membentuk integritas pribadi yang tinggi. Seorang auditor yang memiliki independensi yang tinggi maka kinerjanya akan menjadi lebih baik (Lawalata dkk., 2013). Kode Etik Akuntan Indonesia pasal 1 ayat 2 menyatakan bahwa setiap anggota harus mempertimbangkan Integritas, objektivitas dan Independensi dalam melaksanakan tugasnya. Independensi merupakan faktor yang menentukan dari kualitas audit, hal ini dapat dipahami karena jika auditor benar-benar independen maka tidak akan terpengaruh oleh kliennya, kualitas audit yang baik menandakan bahwa auditor memiliki kinerja yang baik (Elyawati dkk, 2010). Independensi berarti adanya kejujuran dalam diri auditor dalam mempertimbangkan fakta dan adanya pertimbangan yang obyektif tidak memihak dalam diri auditor dalam merumuskan dan menyatakan pendapatnya (Trisnaningsih, 2007). Nilai auditing sangat bergantung pada persepsi publik akan independensi yang dimiliki auditor. Auditor yang menegakkan independensi, akan menunjukkan kejujuran dalam mempertimbangkan fakta dan tidak dipengaruhi oleh berbagai kekuatan yang berasal dari luar diri auditor sehingga hasil kerja yang dicapainya akan semakin baik sesuai standar-standar etika yang telah ditetapkan oleh profesinya. Semakin tinggi independensi auditor, maka kinerja auditor akan semakin baik (Widhi \& Erma, 2015).

Integritas diperlukan agar auditor dapat bertindak jujur dan tegas dalam melaksanakan audit. Integritas merupakan sikap yang dimiliki oleh seorang auditor untuk jujur dan transparan dalam melaksanakan tugasnya dan berani bertanggung jawab atas keputusan yang diambil walaupun akan berdampak kepada dirinya sendiri (Sabirin \& Nurhayati, 2019). Integritas merupakan keadaan dimana suatu individu yang berupaya dalam meningkatkan kepercayaan terhadap publik, maka individu tersebut haruslah memiliki integritas yang tinggi dalam kinerjanya. Integritas juga mewajibkan individu agar taat terhadap standar teknis dan etika yang dimiliki perusahaan (Wijana \& Ramantha, 2015). Integritas berpengaruh pada kinerja auditor, auditor dituntut untuk tetap berani, jujur, bijaksana dan bertanggungjawab guna sebagai dasar untuk pengambilan keputusan yang handal sehingga laporan hasil pemeriksaan yang dihasilkan dapat berkualitas dan dipercaya oleh para pengguna informasi. Kualitas laporan yang baik serta dapat dipercaya akan menjadikan suatu tolak ukur bahwa kinerja dari auditor tersebut baik (Ariani dan Badera, 2014).

Pemahaman good governance merupakan wujud penerimaan akan pentingnya suatu perangkat peraturan atau tata kelola yang baik untuk mengatur hubungan fungsi dan kepentingan berbagai pihak dalam urusan bisnis maupun pelayanan publik. Penerapan good governance pada Kantor Akuntan Publik diharapkan akan memberikan arahan yang jelas pada perilaku kinerja auditor (Hanna \& Friska, 2013). Tuntutan terhadap terwujudnya good governance (tata kelola yang baik) sangat diperlukan, baik oleh perusahaan bisnis manufaktur maupun nonmanufaktur termasuk KAP sendiri. Peran profesi auditor dalam hal ini harus lebih diberdayakan baik secara internal (KAP) maupun eksternal (stakeholder) agar mempunyai kontribusi yang lebih besar dalam mewujudkan good governance tersebut. Pemberdayaan auditor antara lain melalui pemahaman good governance yang lebih baik, dimana aturan yang mengacu prinsip good governance tidak hanya akan mencegah skandal tetapi juga bisa mendongkrak kinerja korporat. Auditor yang memahami good governance secara baik dan benar akan mempengaruhi perilakunya dalam melaksanakan tugas pemeriksaan (auditing) dengan orientasi memperoleh hasil yang baik sehingga kinerja yang dicapai akan semakin lebih baik (Trisnaningsih, 2007).

Berdasarkan latar belakang masalah yang telah dipaparkan, maka peneliti tertarik untuk melakukan penelitian mengenai pengaruh komitmen organisasi terhadap kinerja auditor dengan independensi, integritas, dan pemahaman good governance sebagai variabel moderating pada KAP di Jawa Tengah dan DIY.

Permasalahan dalam penelitian ini (1) apakah komitmen organisasi berpengaruh terhadap kinerja auditor pada KAP di Jawa Tengah dan DIY, (2) apakah independensi dapat memoderasi pengaruh komitmen organisasi berpengaruh terhadap kinerja auditor pada KAP di Jawa Tengah dan DIY. (3) apakah integritas dapat memoderasi pengaruh komitmen organisasi berpengaruh terhadap kinerja auditor pada KAP di Jawa Tengah dan DIY. apakah pemahaman good governance dapat 


\section{Jurnal Akuntansi dan Pajak, 21 (01), 2020, 115}

memoderasi pengaruh komitmen organisasi berpengaruh terhadap kinerja auditor pada KAP di Jawa Tengah dan DIY.

Hipotesis yang diajukan oleh peneliti adalah (1) komitmen organisasi berpengaruh terhadap kinerja auditor pada KAP di Jawa Tengah dan DIY (2) independensi dapat memoderasi pengaruh komitmen organisasi berpengaruh terhadap kinerja auditor pada KAP di Jawa Tengah dan DIY. (3) integritas dapat memoderasi pengaruh komitmen organisasi berpengaruh terhadap kinerja auditor pada KAP di Jawa Tengah dan DIY. (4) pemahaman good governance dapat memoderasi pengaruh komitmen organisasi berpengaruh terhadap kinerja auditor pada KAP di Jawa Tengah dan DIY.

\section{METODE PENELITIAN}

\section{Populasi}

Populasi sasaran dalam penelitian ini adalah Kantor Akuntan Publik (KAP) yang ada di Jawa Tengah dan DIY sebanyak 33 KAP, sedangkan unit analisis dalam penelitian ini adalah seluruh auditor yang bekerja di KAP wilayah Jawa Tengah dan DIY. Teknik pengambilan sampel purposive sampling. Kriteria pemilihan sampel yang digunakan yaitu (1) Responden tidak dibatasi oleh jabatan auditor sehingga semua auditor yang bekerja di KAP dapat diikutsertakan sebagai responden. (2) Auditor mempunyai pengalaman bekerja di KAP minimal 1 tahun, hal ini dilakukan karena auditor tersebut telah memiliki waktu untuk mampu mengenal dan beradaptasi dengan lingkungan kerjanya. Berdasarkan kriteria yang ditetapkan diperoleh jumlah auditor yang memenuhi kriteria sampel yaitu 135 auditor. Dalam kegiatan pengumpulan data, sebanyak 135 eksemplar kuesioner disebar oleh peneliti, sedangkan jumlah kuesioner yang dikembalikan 86 dan kuesioner yang dapat dianalisis sebanyak 48 kuesioner. Dengan demikian peneliti hanya menggunakan sampel sebanyak 48 responden.

\section{Definisi Operasional Variabel}

Komitmen organisasi adalah kekuatan yang bersifat relatif dari auditor dalam mengidentifikasi keterlibatan dirinya ke dalam organisasi. Instrumen komitmen organisasi berbentuk kuesioner terdiri dari 9 item pernyataan, diukur dengan menggunakan dimensi affective dan continuance (Trisnaningsih, 2007).
Independensi auditor adalah sikap auditor untuk tidak terpengaruh dan tidak dipengaruhi oleh berbagai kekuatan dari luar diri auditor dalam mempertimbangkan fakta yang dijumpainya dalam pemeriksaan. Instrumen independensi auditor berbentuk kuesioner terdiri dari 8 item pernyataan, dikur dengan menggunakan tiga dimensi yang dikembangkan oleh Mautz \& Sharaf (dalam Trisnaningsih, 2007) yaitu independensi penyusunan program, independensi investigatif, dan independensi pelaporan.

Integritas adalah sikap auditor untuk jujur dan transparan dalam melaksanakan tugasnya dan berani bertanggung jawab atas keputusan yang diambil walaupun akan berdampak kepada dirinya sendiri. Instrumen integritas berbentuk kuesioner terdiri dari 8 item, diukur dengan menggunakan empat dimensi yaitu sikap jujur, berani, bijaksana dan tanggung jawab terhadap profesi (Utami, 2015).

Pemahaman good governance adalah persepsi auditor mengenai seberapa jauh pemahaman auditor terhadap asas-asas tata kelola perusahaan yang baik. Instrumen pemahaman good governance berbentuk kuesioner terdiri dari 8 item, diukur dengan menggunakan 5 asas GCG terdiri dari 8 item pernyataan terdiri dari transparansi, akuntabilitas, responsibilitas, independensi, serta kewajaran dan kesetaraan (Trisnaningsih, 2007).

Kinerja auditor adalah persepsi auditor mengenai tindakan atau pelaksanaan tugas pemeriksaan yang telah diselesaikan oleh auditor dalam kurun waktu tertentu. Instrumen kinerja auditor berbentuk kuesioner terdiri dari 8 item pernyataan, diukur dengan dengan empat indikator yaitu kemampuan, komitmen profesi, motivasi, dan kepuasan kerja (Trisnaningsih, 2007).

\section{Teknik Pengumpulan Data}

Teknik pengumpulan data menggunakan kuesioner yang diukur dengan skala Likert 5 poin yaitu Sangat Setuju (5), Setuju (4), Netral (3), Tidak Setuju (2). Sangat Tidak Setuju (1).

\section{Pengujian Data}

Untuk menguji kualitas data dilakukan uji validitas dan reliabilitas instrumen menggunakan rumus Korelasi Pearson dan Cronbach Alpha.

\section{Teknik Analisis Data}

a. Uji Asumsi Klasik 


\section{Jurnal Akuntansi dan Pajak, 21 (01), 2020, 116}

Uji Asumsi Klasik dilakukan melalui empat uji yaitu uji multikolinieritas, uji heteroskedastisitas, dan uji normalitas.

b. Teknik analisis data

Teknik analisis data menggunakan analisis regresi dengan metode uji selisih mutlak, dinyatakan dengan persamaan regresi sebagai berikut :

$\mathrm{Y}=\alpha+\beta_{1} \mathrm{X}_{1}+\mathrm{e}$

$Y=a+b_{1} Z X_{1}+b_{2} Z X_{2}+b_{3}\left|Z X_{1}-Z X_{2}\right|+e$

$Y=a+b_{1} Z X_{1}+b_{2} Z X_{3}+b_{3}\left|Z X_{1}-Z X_{3}\right|+e$

$Y=a+b_{1} Z X_{1}+b_{2} Z X_{4}+b_{3}\left|Z X_{1}-Z X_{4}\right|+e$

Keterangan:

$\mathrm{Y}=$ Kinerja auditor

$\mathrm{a}=$ Konstanta

$\beta=$ Koefisien Regresi

$\mathrm{X}_{1}=$ Komitmen organisasi

$\mathrm{X}_{2}=$ Independensi

$\mathrm{X}_{3}=$ Integritas

$\mathrm{X}_{4}=$ Pemahaman good governance

$\mathrm{ZX}_{1}=$ Standardized $\mathrm{X}_{1}$

$\mathrm{ZX}_{2}=$ Standardized $\mathrm{X}_{2}$

$\mathrm{ZX}_{3}=$ Standardized $\mathrm{X}_{3}$

$\mathrm{ZX}_{3}=$ Standardized $\mathrm{X}_{4}$

e $=$ Error

c. Pengujian Hipotesis

Pengujian hipotesis dilakukan dengan uji t, menggunakan tingkat signifikansi $5 \%$.

\section{HASIL DAN PEMBAHASAN}

\section{Hasil Uji Validitas dan Reliabilitas Instrumen}

Hasil uji validitas dengan uji Korelasi Pearson menunjukkan bahwa semua item untuk variabel komitmen organisasi, independensi, integritas, pemahaman good governance dan kinerja auditor semuanya valid, ditunjukkan dengan $p$ value $<0,05$.

Tabel 1

Hasil Uji Validitas

\begin{tabular}{cccccccc}
\hline \multirow{2}{*}{ Item } & \multicolumn{7}{c}{$p$ value } \\
\cline { 2 - 8 } & $\mathrm{X} 1$ & $\mathrm{X} 2$ & $\mathrm{X} 3$ & $\mathrm{X} 4$ & $\mathrm{Y}$ & $\alpha$ & Ket \\
\hline 1 & 0,001 & 0,001 & 0,003 & 0,000 & 0,000 & 0,05 & Valid \\
2 & 0,000 & 0,000 & 0,000 & 0,000 & 0,000 & 0,05 & Valid \\
3 & 0,000 & 0,000 & 0,000 & 0,001 & 0,000 & 0,05 & Valid \\
4 & 0,000 & 0,000 & 0,018 & 0,000 & 0,000 & 0,05 & Valid \\
5 & 0,001 & 0,000 & 0,000 & 0,000 & 0,000 & 0,05 & Valid \\
6 & 0,001 & 0,003 & 0,009 & 0,000 & 0,000 & 0,05 & Valid \\
7 & 0,007 & 0,001 & 0,000 & 0,001 & 0,000 & 0,05 & Valid \\
8 & 0,001 & 0,017 & 0,003 & 0,000 & 0,000 & 0,05 & Valid \\
9 & 0,003 & & & & & 0,05 & Valid
\end{tabular}

Sumber : Data primer diolah, 2019
Berdasarkan uji reliabilitas instrumen diperoleh hasil bahwa instrumen untuk variabel komitmen organisasi, independensi, integritas, pemahaman good governance dan kinerja auditor dinyatakan reliabel karena masing-masing variabel menghasilkan Cronbach Alpha $>0,60$.

Tabel 2

Hasil Uji Reliabilitas Instrumen Cronbach Kriteria

\begin{tabular}{lccc}
\multicolumn{1}{r}{ Variabel } & Alpha & uji & Kesimpulan \\
\hline Komitmen & & & \\
organisasi & 0,757 & 0,60 & Reliabel \\
Independensi & 0,751 & 0,60 & Reliabel \\
Integritas & 0,714 & 0,60 & Reliabel \\
$\begin{array}{l}\text { Pemahaman good } \\
\text { governance }\end{array}$ & 0,814 & 0,60 & Reliabel \\
Kinerja auditor & 0,789 & 0,60 & Reliabel \\
\hline
\end{tabular}

Sumber : Data primer diolah, 2019

\section{Hasil Uji Asumsi Klasik}

Hasil uji asumsi klasik menunjukkan bahwa model regresi linier berganda tidak terjadi masalah multikolinieritas, tidak terjadi masalah heteroskedastisitas, dan residual normal.

Tabel 3

Hasil Uji Asumsi Klasik

\begin{tabular}{|c|c|c|}
\hline $\begin{array}{l}\text { Uji Asumsi } \\
\text { Klasik }\end{array}$ & Hasil Uji & Kesimpulan \\
\hline Uji & Tolerance $(0,974$; & Tidak \\
\hline Multikolinieritas & $\begin{array}{l}0,899 ; 0,972 \\
0,887)>0,1 \\
\operatorname{VIF}(1,027 \\
1,113 ; 1,029 \\
1,128)<10\end{array}$ & $\begin{array}{l}\text { terjadi } \\
\text { multikolini } \\
\text { eritas }\end{array}$ \\
\hline Uji & $p$ value $(0,976$ & Tidak \\
\hline Heteroskedastisitas & $\begin{array}{l}0,758 ; 0,552 \\
0,809)>0,05\end{array}$ & $\begin{array}{l}\text { terjadi } \\
\text { Heterosked } \\
\text { astisitas }\end{array}$ \\
\hline Uji Normalitas & $\begin{array}{l}p \text { value }(0,786)> \\
0,05\end{array}$ & $\begin{array}{l}\text { Residual } \\
\text { normal }\end{array}$ \\
\hline
\end{tabular}

Sumber : Data primer diolah, 2019

\section{Pengujian Hipotesis}

Pengujian hipotesis pada penelitian ini menggunakan analisis regresi dengan model Uji Nilai Selisih Mutlak. Berdasarkan perhitungan dengan program SPSS versi 16 diperoleh hasil uji hipotesis penelitian sebagai berikut: 


\section{Jurnal Akuntansi dan Pajak, 21 (01), 2020, 117}

Tabel 4

Hasil Uji Hipotesis Penelitian Variabel Dependen : Kinerja Auditor

\begin{tabular}{|c|c|c|c|c|c|}
\hline Variabel & $\mathrm{t}$ & & $\mathrm{F}$ & & $R^{2}$ \\
\hline Independen & hitung & $\mathrm{p}$ & hitung & $\mathrm{p}$ & $\mathrm{R}^{-1}$ \\
\hline $\begin{array}{l}\text { Komitmen } \\
\text { organisasi }\end{array}$ & 2,149 & $0,037^{*}$ & 4,618 & 0,037 & 0,091 \\
\hline
\end{tabular}

$\left(\mathrm{X}_{1}\right)$

\begin{tabular}{llllll}
$\begin{array}{l}\text { Moderasi1 } \\
\left(\left|X_{1}-X_{2}\right|\right)\end{array}$ & 2,112 & $0,040 *$ & 7,623 & 0,000 & 0,342 \\
$\begin{array}{l}\text { Moderasi2 } \\
\left(\left|X_{1}-X_{3}\right|\right)\end{array}$ & 2,621 & $0,012 *$ & 5,582 & 0,002 & 0,276 \\
$\begin{array}{l}\text { Moderasi3 } \\
\left(\left|X_{1}-X_{4}\right|\right)\end{array}$ & 2,069 & $0,044 *$ & 5,629 & 0,002 & 0,277 \\
\hline
\end{tabular}

Keterangan : $\mathrm{n}=48 ; * p<0.05$ (one-tailed test).

a. Pengaruh Komitmen Organisasi terhadap Kinerja Auditor

Berdasarkan hasil analisis regresi diperoleh nilai thitung 2,149 dengan $p$ value sebesar 0,037 $<0,05$. Dengan demikian hipotesis 1 diterima, berarti komitmen organisasi berpengaruh signifikan terhadap kinerja auditor. Nilai $\mathrm{F}$ hitung 4,618 dengan $p$ value $0,037<0,05$ berati model fit dalam memprediksi pengaruh komitmen organisasi terhadap kinerja auditor. Nilai koefisien determinasi $R^{2} 0,091$ berarti kontribusi komitmen organisasi dalam menjelaskan kinerja auditor sebesar 9,1\%.

Temuan ini menunjukkan bahwa semakin tinggi komitmen organisasi yang dimiliki auditor maka kinerja auditor yang dihasilkkan akan semakin tinggi. Auditor yang memiliki komitmen tinggi terhadap organisasi tempat bekerja, akan menunjukkan loyalitas, rasa identifikasi, merasa senang bekerja, memiliki sense of belonging (rasa memiliki organisasi), bertanggung jawab dan terlibat lebih banyak dalam memajukan organisasi. Apabila komitmen organisasi yang dimiliki auditor semakin tinggi maka kinerjanya akan semakin baik.

b. Independensi sebagai Pemoderasi pada Pengaruh Komitmen Organisasi terhadap Kinerja Auditor

Berdasarkan hasil analisis regresi dengan metode uji selisih mutlak diperoleh nilai t hitung 2,112 dengan $p$ value sebesar $0,040<0,05$. Dengan demikian hipotesis 2 diterima. Berarti independensi terbukti sebagai variabel pemoderasi yang dapat memperkuat pengaruh komitmen organisasi terhadap kinerja auditor. Nilai $\mathrm{F}$ hitung 7,623 dengan $p$ value $0,000<$ 0,05 berati model fit dalam memprediksi pengaruh komitmen organisasi, independensi, dan moderasi1 terhadap kinerja auditor. Nilai koefisien determinasi $\mathrm{R}^{2} 0,342$ berarti kontribusi komitmen organisasi, independensi, dan moderasi1 dalam menjelaskan kinerja auditor sebesar $34,2 \%$. Dengan melihat perubahan nilai koefisien determinasi dari kedua model, menunjukkan adanya peningkatan nilai $\mathrm{R}^{2}$ sebesar $25,1 \%$ dimana nilai $\mathrm{R}^{2}$ sebelum dimoderasi adalah $9,1 \%$ dan nilai $\mathrm{R}^{2}$ setelah dimoderasi meningkat menjadi $34,2 \%$.

Temuan ini memberikan implikasi bagi KAP di Jawa Tengah dan DIY bahwa peningkatan kinerja auditor dapat semakin optimal apabila komitmen organisasi yang dimiliki auditor semakin didukung dengan independensi yang semakin tinggi.

Auditor yang menegakkan independensinya, tidak akan terpengaruh dan tidak dipengaruhi oleh berbagai kekuatan yang berasal dari luar diri auditor sehingga auditor akan semakin komit melaksanakan tugasnya dengan sebaik mungkin, selanjutnya dapat memberikan kontribusi pada peningkatan kinerja.

c. Integritas sebagai Pemoderasi pada Pengaruh Komitmen Organisasi terhadap Kinerja Auditor

Berdasarkan hasil analisis regresi dengan metode uji selisih mutlak diperoleh nilai t hitung 2,621 dengan $p$ value sebesar 0,012 < 0,05. Dengan demikian hipotesis 3 diterima. Berarti integritas terbukti sebagai variabel pemoderasi yang dapat memperkuat pengaruh komitmen organisasi terhadap kinerja auditor. Nilai F hitung 5,582 dengan $p$ value $0,002<0,05$ berati model fit dalam memprediksi pengaruh komitmen organisasi, integritas, dan moderasi2 terhadap kinerja auditor. Nilai koefisien determinasi $\mathrm{R}^{2} \quad 0,276$ berarti kontribusi komitmen organisasi, integritas, dan moderasi2 dalam menjelaskan kinerja auditor sebesar $27,6 \%$. Dengan melihat perubahan nilai koefisien determinasi dari kedua model, menunjukkan adanya peningkatan nilai $\mathrm{R}^{2}$ sebesar $18,5 \%$ dimana nilai $\mathrm{R}^{2}$ sebelum dimoderasi adalah $9,1 \%$ dan nilai $\mathrm{R}^{2}$ setelah dimoderasi meningkat menjadi $27,6 \%$. 
Temuan ini memberikan implikasi bagi KAP di Jawa Tengah dan DIY bahwa peningkatan kinerja auditor dapat semakin optimal apabila komitmen organisasi yang dimiliki auditor semakin didukung dengan integritas yang semakin tinggi. Auditor memiliki integritas adalah auditor yang bertindak jujur dan tegas dalam melaksanakan audit dan berani bertanggung jawab atas keputusan yang diambil. Pada saat integritas semakin tinggi, auditor akan semakin komit melaksanakan tugasnya dengan sebaik mungkin dengan menunjukkan loyalitas dan kepatuhan terhadap nilai-nilai dan peraturan organisasi, selanjutnya dapat memberikan kontribusi pada peningkatan kinerja.

d. Pemahaman Good Governance sebagai Pemoderasi pada Pengaruh Komitmen Organisasi terhadap Kinerja Auditor

Berdasarkan hasil analisis regresi dengan metode uji selisih mutlak diperoleh nilai t hitung 2,069 dengan $p$ value sebesar 0,044 $<0,05$. Dengan demikian hipotesis 4 diterima. Berarti pemahaman good governance terbukti sebagai variabel pemoderasi yang dapat memperkuat pengaruh komitmen organisasi terhadap kinerja auditor. Nilai $\mathrm{F}$ hitung 5,629 dengan $p$ value $0,002<0,05$ berati model fit dalam memprediksi pengaruh komitmen organisasi, pemahaman good governance, dan moderasi3 terhadap kinerja auditor. Nilai koefisien determinasi $\mathrm{R}^{2}$ 0,277 berarti kontribusi komitmen organisasi, independensi, dan moderasi3 dalam menjelaskan kinerja auditor sebesar $27,7 \%$. Dengan melihat perubahan nilai koefisien determinasi dari kedua model, menunjukkan adanya peningkatan nilai $\mathrm{R}^{2}$ sebesar $18,6 \%$ dimana nilai $\mathrm{R}^{2}$ sebelum dimoderasi adalah $9,1 \%$ dan nilai $\mathrm{R}^{2}$ setelah dimoderasi meningkat menjadi $27,7 \%$.

Temuan ini memberikan implikasi bagi KAP di Jawa Tengah dan DIY bahwa peningkatan kinerja auditor dapat semakin optimal apabila komitmen organisasi yang dimiliki auditor semakin didukung dengan pemahaman yang baik dan benar mengenai peraturan atau tata kelola yang ada pada organisasi KAP. Auditor yang memiliki memahami good governance secara baik dan benar akan menunjukkan sikap dan perilaku kerja positif, sehingga komitmen dalam melaksanakan tugas pemeriksaan (auditing) akan terfokus pada hasil kerja yang semakin baik selanjutnya dapat memberikan kontribusi pada peningkatan kinerja.

\section{KESIMPULAN}

Berdasarkan hasil pengujian setiap hipotesis diperoleh kesimpulan bahwa komitmen organisasi berpengaruh signifikan terhadap kinerja auditor. Independensi terbukti sebagai variabel pemoderasi yang dapat memperkuat pengaruh komitmen organisasi terhadap kinerja auditor. Integritas terbukti sebagai variabel pemoderasi yang dapat memperkuat pengaruh komitmen organisasi terhadap kinerja auditor. Pemahaman good governance terbukti sebagai variabel pemoderasi yang dapat memperkuat pengaruh komitmen organisasi terhadap kinerja auditor.

Sampel penelitian ini hanya terbatas pada auditor di KAP di wilayah Jawa Tengah dan DIY, sehingga hasil penelitian tidak bisa digeneralisir. Dalam penelitian ini, data yang dikumpulkan adalah data primer yang dkumpulkan melalui kuesioner berdasarkan persepsi responden, tidak melakukan survei langsung, sehingga ada kemungkinan mengandung kelemahan mengenai validitas internal. Auditor diharapkan untuk lebih meningkatkan komitmennya dalam organisasi KAP, sehingga auditor mempunyai rasa tanggung jawab kepada organisasinya untuk meningkatkan kinerja yang lebih baik. Penelitian selanjutnya diharapkan dapat menambahkan variabel pemoderasi lain.

\section{REFERENSI}

Ariani, Komang Gunayanti dan I Dewa Nyoman Badera. 2015. Pengaruh Integritas, Obyektifitas, Kerahasiaan, Dan Kompetensi Pada Kinerja Auditor Inspektorat Kota Denpasar. E-jurnal Akuntansi Universitas Udayana, 10(1): 182198.

Elyawati, Lismawati dan Nila Aprilla, 2010, Independensi, Gaya Kepemimpinan, Komitmen Organisasi, dan Pemahaman Good Governance terhadap Kinerja Auditor Pemerintah (Studi Pada Auditor Pemerintah di BPKP Perwakilan Bengkulu), Simposium Nasional Akuntansi- SNA XIII, Purwokerto: 1-25.

Fanani, Z., Hanif, R.A., dan Subroto, B. 2008. Pengaruh Struktur Audit, Konflik Peran, dan Ketidakjelasan Peran terhadap Kinerja Auditor. Jumal Akuntansi dan Keuangan Indonesia, 5(2): 139-155. 
Fembriani, Astrid dan I Ketut Budiartha, 2016, Faktor-Faktor Yang Mempengaruhi Kinerja Auditor BPK RI Perwakilan Provinsi Bali, EJurnal Ekonomi dan Bisnis Universitas Udayana, 5(3): 601-628.

Halim, A., Sutrisno, Rosidi, and M. Achsin. 2014. Effect of Competence and Auditor Independence on Audit Quality with Audit Time Budget and Professional Commitment as a Moderation Variabel. International Journal of Business and Management Invention, 3(6): 64-74.

Hanna, Elizabeth dan Friska Firnanti, 2013, Faktorfaktor yang Mempengaruhi Kinerja Auditor, Jurnal Bisnis dan Akuntansi, 15(1): 13-28.

Haryono, J. 2010. Auditing Pengauditan. Bagian Penerbitan Sekolah Tinggi ilmu Ekonomi YKPN, Yogyakarta.

Hutabarat, G. 2012. Pengaruh Pengalaman, Time Budget Pressure dan Etika Auditor terhadap Kualitas Audit. Jurnal Ilmiah ESAI, 6(1): 1-14. Julianingtyas, Bunga Nur, 2012, Pengaruh Locus Of Control, Gaya Kepemimpinan Dan Komitmen Organisasi Terhadap Kinerja Auditor, Accounting Analysis Journal, 1(1): 7-14.

Lawalata, J., Darwis Said, dan Mediaty, 2013, Pengaruh Independensi Auditor, Komitmen Organisasi, Gaya Kepemimpinan dan Budaya Organisasi terhadap Kinerja Auditor (Studi Empiris pada Kantor Akuntan Publik di Makasar). Jurnal Universitas Hasanurdin, Makasar: 1-10.

Mindarti, Ceacilia Sri, 2015, Pengaruh Karakteristik Individu terhadap Kinerja Auditor, Jurnal Ekonomi dan Bisnis, 18(3): 59-74.

Mulyadi. 2002. Auditing. Edisi 6 cetakan ke 1, Salembang Empat, Jakarta.

Novatiani, R.A. dan Mustofa, T., 2014, Pengaruh Profesionalisme Auditor Internal dan Komitmen Organisasi Auditor Internal terhadap Kinerja Auditor Internal (Studi Kasus pada Inspektorat Kabupaten Purwakarta), Conference on Management and Behavioral Studies (CMBS) 2014: 104-110.

Putra, Kadek Arya Adi dan Dodik Ariyanto, 2016, Gaya Kepemimpinan, Pemahaman Good Governance, Locus of Control, Struktur Audit dan Komitmen Organisasi, E-Jurnal Akuntansi Universitas Udayana, 14 (1): 340-370.
Robbins, S.P., and Timothy A.J. 2007. Organizational Behavior. Pearson International Edition, 13th. Edition. Upper Saddle River, New Jersey

Sabirin dan Nurhayati, Y.S. 2019. Pengaruh Locus of Control, Integritas Auditor, Dan Gaya KepemimpinanTerhadap Kinerja Auditor Studi Kasus Pada Kantor Akuntan Publik di Kota Bandung. Akuntansi Dewantara, 3(1): 22-37.

Sanjiwani, Desak Made Putri dan I Gede Suparta Wisadha, 2016, Pengaruh Locus Of Control, Gaya Kepemimpinan dan Komitmen Organisasi pada Kinerja Auditor Kantor Akuntan Publik, EJurnal Akuntansi Universitas Udayana, 14(2): 920-947.

Sapariyah, R., A. 2011. Pengaruh Good Governance dan Independensi Auditor Terhadap Kinerja Auditor dan Komitmen Organisasi (Survey Pada Kantor Akuntan Publik di Surakarta). Jurnal Ekonomi Bisnis dan Perbankan.

Somers and Birnbaum. 1998. Work-Related Commitment and Job Performance: It's Also The Nature of The Performance That Counts. Journal of Organizational Behavior, (19): 621634.

Sri Trisnaningsih, 2007. Independensi Auditor dan Komitmen Organisasi Sebagai Mediasi Pengaruh Pemahaman Good Governance, Gaya Kepemimpinan dan Budaya Organisasi Terhadap Kinerja Auditor. Jurnal SNA X. Unhas Makasar.

Suryana, Fajar Hadi. 2013. Pengaruh Struktur Audit, Komitmen Organisasi, Konflik Peran dan Efektivitas Penggunaan Teknologi Sistem Informasi Akuntansi terhadap Kinerja Auditor. Jurnal. UIN Syrif Hidayatullah Jakarta.

Trisnaningsih, S., 2007, Independensi Auditor dan Komitmen Organisasi sebagai Mediasi Pengaruh Pemahaman Good Governance, Gaya Kepemimpinan dan Budaya Organisasi terhadap Kinerja Auditor, SNA-Simposium Nasional Akuntansi X Makasar: 1-56.

Utami, U.I. 2015. Pengaruh Integritas, Obyektivitas, Kerahasiaan, Kompetensi, Dan Pengalaman Kerja Terhadap Kinerja Auditor Pada Inspektorat Provinsi Riau. Jom. FEKON. 2(2):114. 
Jurnal Akuntansi dan Pajak, 21 (01), 2020, 120

Widhi, S.N. dan Erma, S., 2015, Pengaruh Independensi, Gaya Kepemimpinan, Komitmen Organisasi Dan Pemahaman Good Governance Terhadap Kinerja Auditor Pemerintah, BENEFIT Jurnal Manajemen dan Bisnis, 19(1): 64-79.
Wijana, D.G.A. dan Ramantha, I.W. 2015. Interitas Sebagai Pemoderasi Pengaruh Komitmen Organisasi Pada Kinerja Auditor. E-Jurnal Akuntansi Universitas Udayana, 10(3): 841851. 